\title{
Influence of seedling age on growth, productivity and heat use efficiency of rice genotypes in North West India
}

\author{
BUTA SINGH DHILLON ${ }^{1}$, GURPREET KAUR ${ }^{1}$, G.S. MANGAT ${ }^{1}$ and PRABHJYOT-KAUR ${ }^{2}$ \\ ${ }^{1}$ Department of Plant Breeding and Genetics, ${ }^{2}$ Department of Climate Change and Agricultural Meteorology, \\ Punjab Agricultural University, Ludhiana, Punjab -141004 \\ Corresponding author email: bsdhillon@pau.edu
}

\begin{abstract}
An experiment was conducted at Punjab Agricultural University, Ludhiana, India during kharif 2017 and 2018 to determine the effect of seedling age on growth, phenology and thermal energy utilization by different rice genotypes. The field experiment was laid-out in factorial RCBD design keeping three seedling age (25, 35, 45 days) and four rice genotypes (PR 121, PR 122,PR 124, PR 126) with three replicates. The prevalence of dry weather conditions especially during September month of 2017, which coincides with grain growth phase was congenial for rice crop and was reflected in the yield and yield attributes. There was consistent decline in grain and straw yield of rice with increase in seedling age due to reduced leaf area index (LAI), dry matter partitioning to grain/culm and SPAD value. This may be due to prevalence of higher range of minimum temperature resulting into more respiratory losses and thereby leading to lower heat use efficiency. Among genotypes, PR 126 was found to be most heat use efficient owing to its shorter duration (93.9 days), where as PR 121 and PR 122 recorded the highest grain and straw yield due to higher accumulation of growing degree and more congenial temperature leading to more number of panicles $\mathrm{m}^{-2}$ along with the bold grains. It was also observed that increasing seedling age beyond 25 days caused sharp decline in grain and straw yield of PR 124 and PR 126 through effect on panicles $\mathrm{m}^{-2}, \mathrm{SPAD}$ value and AGDD; while PR 121 and PR 122 gave similar yield when transplanted using 25 to 45 days older seedlings. Harvest index did not differ due to various treatments.
\end{abstract}

Key words : Dry matter, harvest index, heat use efficiency, grain yield, seedling age

Crop productivity is a result of complex interactions between genetic, environmental and cultural management factors (Dhillon et al., 2017). Amongst these three factors, environmental factors play a key role as they are least manageable, while genetic and cultural management factors in a crop are within the control of the grower. Among the cultural management of transplanted rice, the selection of appropriate genotype and its transplanting at the appropriate age are the most important cultural decisions for obtaining higher productivity(Faghani et al., 2011). With the increased scarcity of farm labour and paucity of irrigation water for puddling during peak transplantation period, the transplantation of nursery seedlings is often delayed under Punjab conditions, thereby increasing the seedling age in nursery bed itself. When seedlings stay for an extended period of time in the beds of nursery, primary tiller buds on the lower nodes of main culm become degenerated leading to reduced tillering potential (Mobasser et al., 2007). Transplanting older nursery seedlings besides reducing tiller production also results in early panicle initiation, uneven flowering, shortening vegetative phase and thereby reducing number of grains per panicle (Jia et. al.2014). Pre anthesis dry matter accumulation determines the sink capacity and final grain yield. Optimum seedling age for transplanting varies with genotypes due to variation in their crop duration, phenology and tillering potential (Mobasser et. al., 2007). The ability of the crop to utilize heat energy for dry matter accumulation is determined by environmental conditions in addition to genetic factors (Rao et. al., 1999). Rice is determined plant and reaches flowering stage at almost fixed time as this character is under strong genetic control.Varying seedling age is supposed to cause variation in occurrence of phenological events of rice crop. Coinciding the crop phenology with favorable environment by selecting the appropriate cultural practices is crucial for attaining higher yield. Growing degree days (GDD), which determine occurrence of various phenological events in the life cycle of a plant, is the most common agro-climatic index used to estimate phenological development of a plant (Kaur and Prabhjyot-Kaur, 2014). Hence, studies were conducted to find out optimum seedling age of rice genotypes for obtaining higher productivity and heat use efficiency. 


\section{MATERIALS AND METHODS}

Field experiments were conducted at Research Farm of Punjab Agricultural University, Ludhiana, India [30 $30^{\circ} 6^{\prime}$ Nlatitude; $75^{\circ} 52^{\prime} \mathrm{E}$ longitude; $247 \mathrm{~m}$ altitude] located in the Indo-Gangetic Plains Region (IGPR) during kharif 2017 and 2018. Climate of experimental site is characterized as subtropical, semi-arid with an annual rainfall of $759 \mathrm{~mm}$, out of which about $80 \%$ is received from June to September (Prabhjyot-Kaur et al., 2016). The data on meteorological parameters were measured at agro-meteorological observatory of Punjab Agricultural University, Ludhiana (Table 1 and Fig. 1). The soil of the experiment site was sandy-loam in texture, low in available $\mathrm{N}$ status and high in available-P but medium in available-K and soil organic carbon (SOC) status. The soil $\mathrm{pH}$ and electrical conductivity were within the normal range.

The field experiments were laid-out in Randomized Complete Block Design with three replicates, keeping three seedling age (25, 35, 45 days) and four rice genotypes (PR 121, PR 122,PR 124, PR 126). All the genotypes were transplanted on June $20^{\text {th }}, 2017$ and June $24^{\text {th }} 2018$ at a spacing of $15 \times 20 \mathrm{~cm}$. All production and protection technologies were followed as per recommendations of Punjab Agricultural University, Ludhiana.

Plant height was recorded from five randomly tagged plants in each experimental unit and it was measured from the ground level to the top of panicle and expressed in centimetres. Digital Plant Canopy Imager (CID, Inc. CI-110/ CI-120) was used to record leaf area index (LAI) at 50 per cent flowering stage. SPAD reading was noted at 50 per cent flowering stage from fully expanded apical leaves, using KONICA MINOLTA SPAD-502 PlusS/N:20001083 VER: 1.00.0501 model. For recording dry matter partitioning at physiological maturity, five plants were cut at ground level from each experimental units and separated into different plant parts, which were dried at $65^{\circ} \mathrm{C} \pm 2^{\circ} \mathrm{C}$ in an oven till attainment of constant weight. Phenological traits were noted on the basis of visual observations from whole of experimental unit (treatment plot). Physiological maturity was also noted visually as and when panicles were ripe and straw turned golden yellow. Growing degree days (GDD) were determined by "Remainder index" method as per Nuttonson (1955) using a base temperature of $10.0^{\circ} \mathrm{C}$ (Kaur and Prabhjyot-Kaur, 2014). Heat use efficiency (HUE) for grains and straw was computed by dividing the grain yield or straw yield with accumulated GDD and expressed as $\mathrm{kg}$ ha $^{-1{ }^{\circ}} \mathrm{C}^{-1}$ day.
Five panicles were randomly selected from each experimental unit for recording panicle weight, grain weight per panicle, number of filled and unfilled grains. For recording grain yield, the grains obtained after threshing net plot were sun dried, winnowed, cleaned and weighed on an electronic balance. For valid comparison of different treatments, moisture in grains was estimated using moisture meter. Grain yield was adjusted at $14 \%$ moisture and expressed as $q$ ha ${ }^{1}$. The weight of straw from each net plot was also recorded three days after harvest for estimation of straw yield, which was expressed as $\mathrm{q} \mathrm{ha}^{-1}$. Data were subjected to statistical analysis using SAS 9.3 software package.

\section{RESULTS AND DISCUSSION}

\section{Ambient environmental conditions}

Among the two crop seasons, the maximum and minimum temperature (Table 1) were higher by 0.6 and $0.2^{\circ} \mathrm{C}$, respectively during kharif 2017 as compared to 2018 due to clear sky conditions, i.e. sunshine hour more by 171 hour (Fig. 1) and dry weather, i.e. rainfall less by $448.2 \mathrm{~mm}$. It is further evident that the mean maximum and mean minimum temperature remained higher under 45 day's old seedling treatment as compared to 35- and 25-days old seedling treatments (Table 2). Databrings out that hike in mean maximum temperature under 45 days old seedlings treatment as compared to 25 days old seedling was just 0.3 to $0.4{ }^{\circ} \mathrm{C}$ but mean minimum temperature difference under similar treatments were to the tune of $0.7^{\circ} \mathrm{C}$ due to prevalence of higher range of minimum temperature, leading to hike in respiration rate resulting into lower net photosynthesis. Although the range of maximum temperature remained between $25.9-37.4^{\circ} \mathrm{C}$ and $22.0-36.0^{\circ} \mathrm{C}$ in all seedling age treatmentsbut range of minimum temperature in 25 days seedling treatment lies between $12.0-29.2^{\circ} \mathrm{C}$ and $8.6-29.2^{\circ} \mathrm{C}$, which was $13.2-29.2^{\circ} \mathrm{C}$ and $8.6-29.6^{\circ} \mathrm{C}$ under 35 - and $45-$ days old seedling treatments during 2017 and 2018, respectively. Among the genotypes, PR 122 experienced the least but PR 126 experienced the highest maximum and minimum temperature. The higher temperature might have lowered the productivity by way of increasing sterility (Table 6) and respiratory losses.

\section{Crop phenology}

The increase in age of seedling caused consistent reduction in number of days taken to reach 50 per cent flowering as well as physiological maturity stage (Table 2). It is also evident that older seedlings caused more reduction in reproductive phase (seed filling period) than vegetative phase. Jia et al. (2014) also reported early panicle initiation, 
Table 1: Mean monthly meteorological data during crop growth season (Kharif 2017 and 2018)

\begin{tabular}{|c|c|c|c|c|c|c|c|c|}
\hline \multirow[t]{2}{*}{ Month } & \multicolumn{2}{|c|}{ Maximum Temp $\left({ }^{\circ} \mathrm{C}\right)$} & \multicolumn{2}{|c|}{ Minimum Temp $\left({ }^{\circ} \mathrm{C}\right)$} & \multicolumn{2}{|c|}{ Mean Temp $\left({ }^{\circ} \mathrm{C}\right)$} & \multicolumn{2}{|c|}{ Rainfall (mm) } \\
\hline & 2017 & 2018 & 2017 & 2018 & 2017 & 2018 & 2017 & 2018 \\
\hline June & 36.7 & 37.6 & 26.2 & 27.1 & 31.5 & 32.3 & 127.0 & 141.8 \\
\hline July & 34.6 & 34.2 & 27.6 & 26.6 & 31.1 & 30.4 & 112.0 & 376.6 \\
\hline August & 33.9 & 34.1 & 26.7 & 27.2 & 30.3 & 30.6 & 131.4 & 74.0 \\
\hline September & 33.7 & 32.0 & 23.9 & 23.9 & 28.8 & 27.9 & 24.4 & 250.6 \\
\hline October & 33.3 & 31.3 & 18.8 & 17.1 & 26.1 & 24.2 & 0 & 0 \\
\hline Mean/Total & 34.4 & 33.8 & 24.6 & 24.4 & 29.6 & 29.1 & 394.8 & 843.0 \\
\hline
\end{tabular}

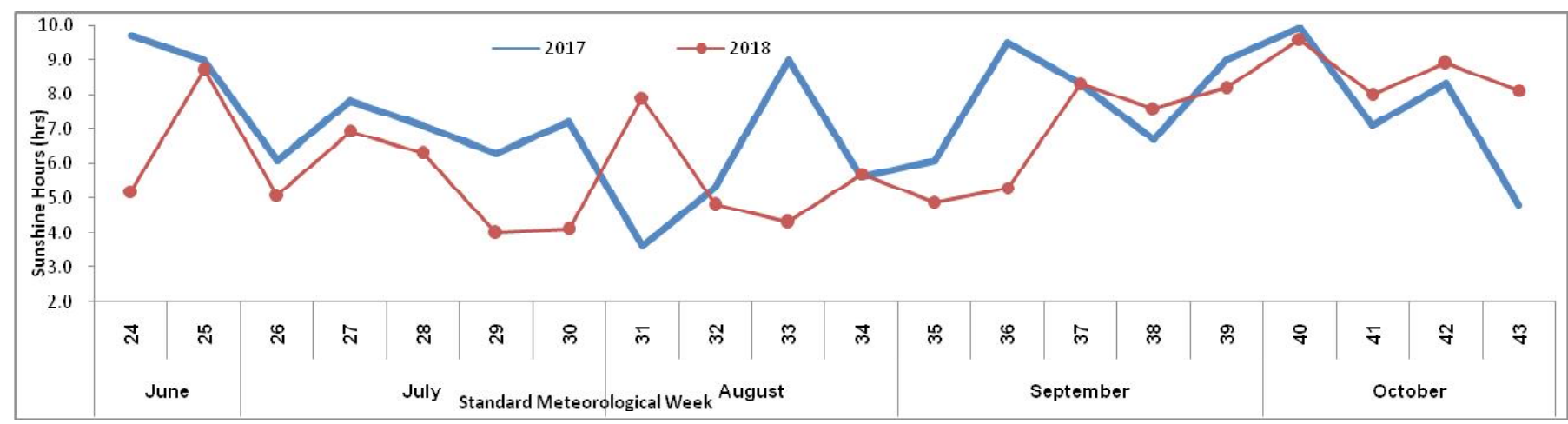

Fig. 1: Weekly sunshine hours variability at Ludhiana during rice seasons of 2017 and 2018

uneven flowering, and shortening vegetative phase of rice in response to older seedling age. It is further evident that PR 126 took the least number of days (62.8 and 93.9) followed by PR 124 (75.7 and 109.1), PR 121 (80.9 and 112.8) and PR 122 (85.7 and 118.7) in increasing order to reach 50 per flowering and physiological maturity stage. The duration of reproductive period was more for PR 122 and PR 124. The duration of reproductive period was prolonged during 2018 as compared to 2017 due to prevalence of lower maximum temperature during the month of September (by $1.7^{\circ} \mathrm{C}$ ) and October (by $2.0^{\circ} \mathrm{C}$ ). This reduction in daytime temperature was due to $226.2 \mathrm{~mm}$ more rainfall received during September 2018 (Table 1).

\section{Growth attributes, dry matter partitioning and SPAD value}

Increase in seedling age caused consistent decline in LAI and dry matter portioning to leaf, culm and grain with (Table 3 and Fig. 2), which may be linked with higher tiller count. Liu et al. (2017) also reported that the younger seedlings produce more number of tillers per unit area. They further reported that with the increase in the age of rice seedlings amount of pre-anthesis dry matter remobilization, post-anthesis photosynthesis along with its efficiency and contribution to the grain yield are decreased. It is further evident that $P R 122$ produced the tallest plants, whereas, $P R$ 121 produced the shortest plants during both the years of study. Plant height of PR 124 and PR 126 was statistically similar to each other during both the years but during kharif 2018, PR 121was also similar to PR 124 and PR 126. Although LAI and dry matter partitioning to leaf as well as to chaff was similar under all genotypes but dry matter partitioning to culm and grain by PR 121 and PR 122 was significantly more than PR 124 and PR 126 (Fig. 2).

Data in Table 4 reveals that irrespective of genotypes, transplanting 25 days old seedlings resulted in the highest SPAD value at $50 \%$ flowering stage. Data further brings out that increasing seedling age beyond 25 days did not caused significant decline in SPAD value of PR 121 and PR 122 but in case of PR 124 and PR 126, there was significant decline in SPAD value, when seedling age was increased to 35 days from 25 days. Such a decrease can be ascribed to the temporal variation/reduction in sunshine hour during end August to early September (Fig. 1) during which the crop reached 50\% flowering stage. The reduction in chlorophyll content due to transplanting of aged seedlings have also been reported by Pramanik and Bera (2013). 


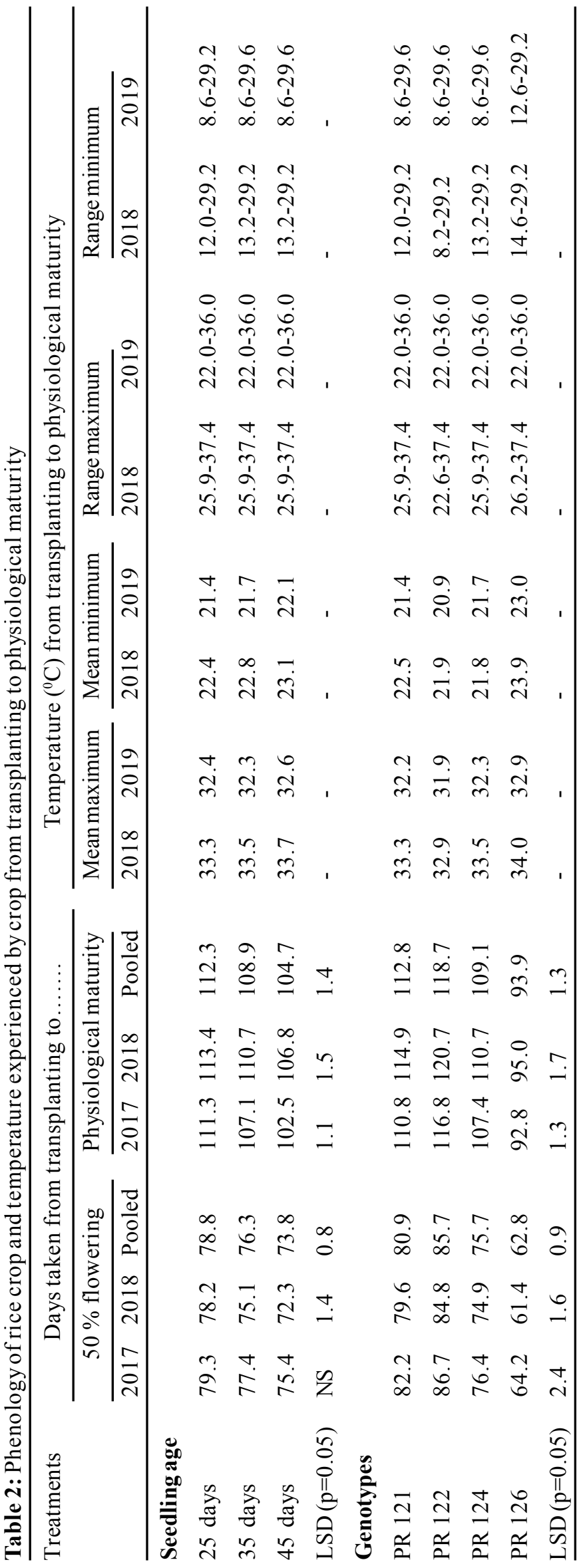

Accumulated growing degree days (AGDD) and heat use efficiency (HUE)

During 2018 due to prevalence of lower temperature the AGDD from 50 per cent flowering to physiological maturity were reduced. With an increase in seedling age, there was a consistent decline in accumulated growing degree days (AGDD) between transplanting to 50 per cent flowering and up to physiological maturity stage (Table 5) which indirectly reduced the heat use efficiency. Due to different growth duration of four genotypes, there was significant variation in AGDD accrued and HUE achieved. The genotypes, PR 126 accumulated least number of GDD, whereas; PR 122 accumulated the highest number of GDD to reach 50 per flowering stage as well as physiological maturity stage. But this difference between PR 126 and PR 122 were narrowed down as the crop reached physiological maturity stage. However, the highest HUE for grains was recorded by PR 126, which was statistically similar to PR 121; whereas; PR 122 and PR 124 recorded the least HUE for grains. Similar trend was observed for HUE of genotypes for straw (Table 5).

\section{Yield and yield attributes}

The significant influence of seedling age on number of panicles per unit area was clearly evident but its effect on other yield attributes were not statistically significant (Table 6). Although decline due to each successive older seedling age was not appreciable but significant differences existed among 35- and 45-days seedling during 2018 and in pooled analysis (Table 6). Grain yield is a complex heritable character influenced by many morphological, physiological and biochemical attributes of the plant interacting with environment. It is evident that the effect of thermal indices and yield attributes was also translated into grain and straw yield as there was consistent decline in grain and straw yield of rice with increase in seedling age (Table 8). Among the two crop years, an invariably cloudy weather during 2018 exposed the crop to a gradual radiative stress (Fig. 1) and this was translated in the yield and yield attributes of rice cultivars. Effects on harvest index were not significant.

The perusal of data revealed that PR 121 recorded the highest panicles $\mathrm{m}^{-2}$, followed by PR 122, PR 126 and PR 124 in decreasing orders (Table 6 and 7). The highest panicle weight and number of filled grains per panicle were recorded in PR 126 followed by PR 124 and PR 121 in decreasing order. Although panicle weight of PR 121 was statistically similar to PR 122 but number of filled grains per panicle in PR 121 were significantly lower than PR 122. The highest 
Table 3: Effect of seedling age and varieties on growth parameters of rice

\begin{tabular}{llllllll}
\hline Treatments & \multicolumn{3}{c}{ Plant height $(\mathrm{cm})$ (at harvest) } & & \multicolumn{3}{c}{ Leaf area index (at 50 per cent flowering) } \\
\cline { 2 - 3 } Seedling age & 2017 & 2018 & Pooled & & 2017 & 2018 & Pooled \\
\hline 25 days & 105.0 & 108.9 & 106.9 & & 4.01 & 3.97 & 3.99 \\
35 days & 104.2 & 107.2 & 105.7 & & 3.93 & 3.82 & 3.88 \\
45 days & 104.2 & 106.4 & 105.3 & & 3.73 & 3.61 & 3.66 \\
LSD (p=0.05) & NS & NS & NS & & 0.19 & 0.16 & 0.14 \\
Genotypes & & & & & & 3.89 & 3.89 \\
PR 121 & 99.1 & 104.2 & 101.6 & & 3.95 & 3.89 & 3.82 \\
PR 122 & 110.8 & 115.5 & 113.1 & & 3.84 & 3.82 & 3.84 \\
PR 124 & 104.4 & 105.6 & 105.0 & & 3.90 & 3.84 & 3.85 \\
PR 126 & 103.6 & 104.6 & 104.1 & & 3.87 & 3.85 & NS \\
LSD (p=0.05) & 2.7 & 2.9 & 2.0 & & NS & NS &
\end{tabular}

Table 4: Interactive effect of seedling age on SPAD value of rice varieties at 50 per cent flowering stage

\begin{tabular}{|c|c|c|c|c|c|c|c|c|c|c|c|c|}
\hline \multirow[t]{2}{*}{ Genotype } & \multicolumn{4}{|c|}{2017} & \multicolumn{4}{|c|}{2018} & \multicolumn{4}{|c|}{ Pooled } \\
\hline & 25 Days & 35 days & 45 days & Mean & 25 Days & 35 days & 45 days & Mean & 25 Days & 35 days & 45 days & Mean \\
\hline PR 121 & 39.0 & 36.9 & 39.0 & 38.3 & 41.6 & 39.3 & 39.5 & 40.1 & 40.3 & 38.1 & 39.3 & 39.2 \\
\hline PR 122 & 43.6 & 44.4 & 43.3 & 43.8 & 39.8 & 40.4 & 40.9 & 40.4 & 41.7 & 42.4 & 42.1 & 42.1 \\
\hline PR 124 & 39.8 & 41.6 & 39.7 & 40.4 & 42.1 & 39.2 & 38.7 & 40.0 & 40.9 & 40.4 & 39.2 & 40.2 \\
\hline PR 126 & 29.3 & 31.7 & 28.0 & 29.7 & 42.0 & 37.9 & 37.2 & 39.0 & 35.7 & 34.8 & 32.6 & 34.4 \\
\hline Mean & 37.9 & 38.7 & 37.5 & & 41.4 & 39.2 & 39.1 & & 39.7 & 38.9 & 38.3 & \\
\hline \multicolumn{2}{|c|}{$\operatorname{LSD}(p=0.05)$} & \multicolumn{3}{|c|}{$\begin{array}{l}\text { Seedling age: NS; } \\
\text { Genotypes: } 2.3 \text {; } \\
\text { Interaction: NS }\end{array}$} & \multicolumn{4}{|c|}{$\begin{array}{l}\text { Seedling age: } 1.0 \text {; } \\
\text { Genotypes: NS; } \\
\text { Interaction: } 2.0\end{array}$} & \multicolumn{4}{|c|}{$\begin{array}{l}\text { Seedling age: } 10 \text {; } \\
\text { Genotypes: } 1.2 \text {; } \\
\text { Interaction: NS }\end{array}$} \\
\hline
\end{tabular}
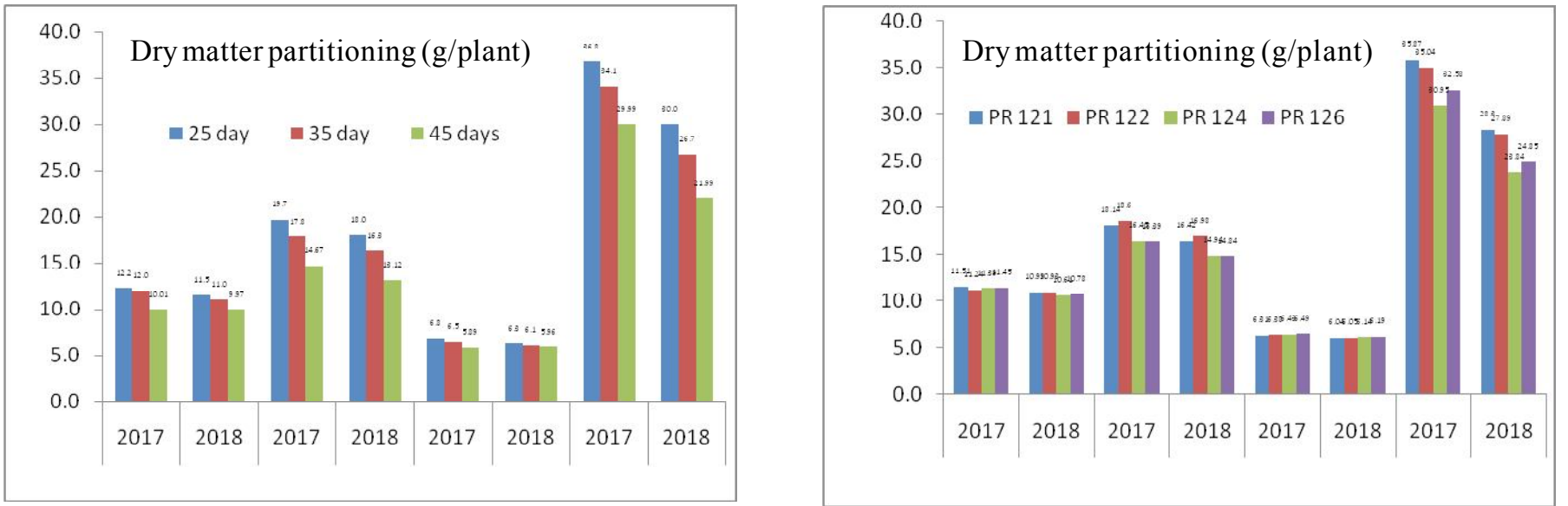

Fig. 2: Dry matter partitioning (g/plant) under various treatments

1000 grain weight was noted in case of PR 121 (26.5 g), whereas the least in case of PR $126(21.2 \mathrm{~g})$. Likewise, PR $124(24.8 \mathrm{~g})$ and PR $122(24.0 \mathrm{~g})$ were mediocre with significant differences amongst all genotypes. Sterility was the least in case of PR 122 than all other genotypes. The highest grain and straw yield was observed under PR 121 


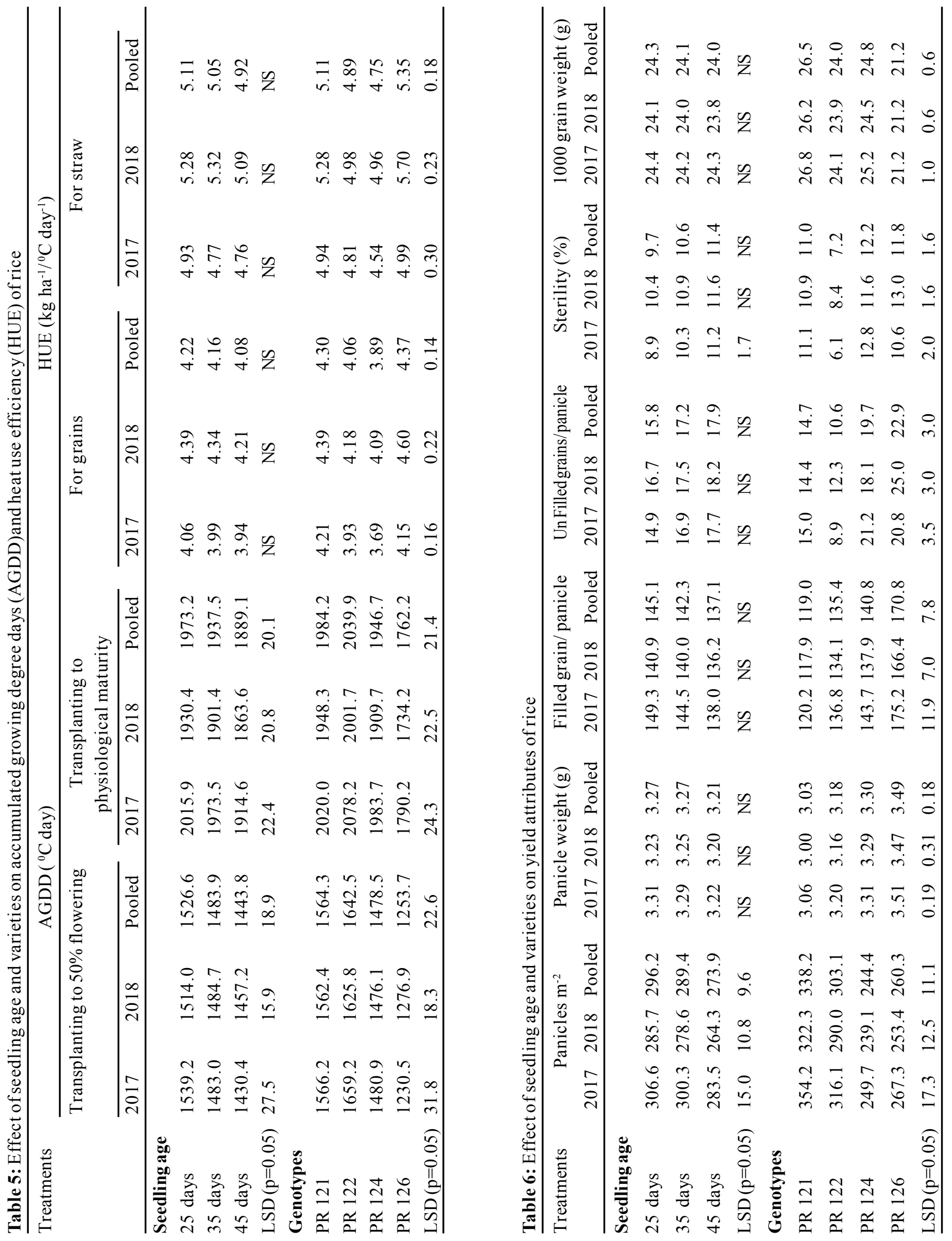


Table 7: Interactive effect of seedling age on panicles $/ \mathrm{m}^{2}$ of rice varieties

\begin{tabular}{|c|c|c|c|c|c|c|c|c|c|}
\hline \multirow[t]{2}{*}{ Genotypes } & \multicolumn{3}{|c|}{2017} & \multicolumn{3}{|c|}{2018} & \multicolumn{3}{|c|}{ Pooled } \\
\hline & 25 Days & 35 days & 45 days & 25 Days & 35 days & 45 days & 25 Days & 35 days & 45 days \\
\hline PR 121 & 358.5 & 348.7 & 355.3 & 326.7 & 327.8 & 312.4 & 342.6 & 338.3 & 333.9 \\
\hline PR 122 & 313.5 & 311.3 & 323.4 & 284.9 & 288.2 & 297.0 & 299.2 & 299.8 & 310.2 \\
\hline PR 124 & 262.9 & 265.1 & 221.1 & 255.2 & 240.9 & 221.1 & 259.1 & 253.0 & 221.1 \\
\hline PR 126 & 291.5 & 276.1 & 234.3 & 276.1 & 257.4 & 226.6 & 283.8 & 266.8 & 230.5 \\
\hline \multicolumn{2}{|c|}{$\operatorname{LSD}(p=0.05)$} & 30.0 & 21.6 & 19.2 & & & & & \\
\hline
\end{tabular}

Table 8: Effect of seedling age and varieties on grain, straw yield and harvest index of rice

\begin{tabular}{|c|c|c|c|c|c|c|c|c|c|}
\hline \multirow[t]{2}{*}{ Treatments } & \multicolumn{3}{|c|}{ Grain yield $\left(\mathrm{q} \mathrm{ha}^{-1}\right)$} & \multicolumn{3}{|c|}{ Straw yield $\left(\mathrm{q} \mathrm{ha}^{-1}\right)$} & \multicolumn{3}{|c|}{ Harvest index $(\%)$} \\
\hline & 2017 & 2018 & Pooled & 2017 & 2018 & Pooled & 2017 & 2018 & Pooled \\
\hline \multicolumn{10}{|l|}{ Seedling age } \\
\hline 25 days & 84.4 & 81.6 & 83.0 & 101.6 & 99.3 & 100.4 & 45.4 & 45.1 & 45.3 \\
\hline 35 days & 82.4 & 78.6 & 80.5 & 100.8 & 94.1 & 97.5 & 45.0 & 45.5 & 45.3 \\
\hline 45 days & 78.6 & 75.4 & 77.0 & 94.7 & 91.1 & 92.9 & 45.3 & 45.3 & 45.3 \\
\hline $\operatorname{LSD}(p=0.05)$ & 3.7 & 2.8 & 2.4 & 3.7 & 5.2 & 3.0 & NS & NS & NS \\
\hline \multicolumn{10}{|l|}{ Genotypes } \\
\hline PR 121 & 85.6 & 85.0 & 85.3 & 102.8 & 99.9 & 101.4 & 45.4 & 46.0 & 45.7 \\
\hline PR 122 & 83.6 & 81.7 & 82.7 & 99.6 & 99.8 & 99.7 & 45.6 & 45.1 & 45.4 \\
\hline PR 124 & 78.1 & 73.2 & 75.7 & 94.8 & 90.1 & 92.4 & 45.2 & 44.8 & 45.0 \\
\hline PR 126 & 79.9 & 74.3 & 77.1 & 98.9 & 89.5 & 94.2 & 44.6 & 45.4 & 45.0 \\
\hline $\operatorname{LSD}(p=0.05)$ & 4.3 & 3.3 & 2.8 & 4.2 & 5.6 & 3.4 & NS & NS & NS \\
\hline
\end{tabular}

Table 9: Interactive effect of seedling age on grain yield $\left(\mathrm{q} \mathrm{ha}^{-1}\right)$ of rice varieties

\begin{tabular}{|c|c|c|c|c|c|c|c|c|c|}
\hline \multirow[t]{2}{*}{ Genotypes } & \multicolumn{3}{|c|}{2017} & \multicolumn{3}{|c|}{2018} & \multicolumn{3}{|c|}{ Pooled } \\
\hline & 25 Days & 35 days & 45 days & 25 Days & 35 days & 45 days & 25 Days & 35 days & 45 days \\
\hline PR 121 & 85.6 & 85.3 & 85.8 & 85.5 & 85.4 & 84.0 & 85.6 & 85.3 & 84.9 \\
\hline PR 122 & 81.7 & 86.1 & 83.0 & 81.5 & 82.6 & 81.0 & 81.6 & 84.4 & 82.0 \\
\hline PR 124 & 82.7 & 77.4 & 74.3 & 78.8 & 72.3 & 68.6 & 80.8 & 74.9 & 71.4 \\
\hline PR 126 & 87.7 & 80.9 & 71.1 & 80.6 & 74.2 & 68.1 & 84.1 & 77.5 & 69.6 \\
\hline $\operatorname{LSD}(p=0.05)$ & 7.4 & 5.7 & 4.8 & & & & & & \\
\hline
\end{tabular}

Table 10: Interactive effect of seedling age on straw yield $\left(\mathrm{q} \mathrm{ha}^{-1}\right)$ of rice varieties

\begin{tabular}{llllllll}
\hline Genotypes & \multicolumn{3}{c}{2017} & & \multicolumn{3}{c}{ Pooled } \\
\cline { 2 - 3 } & 25 Days & 35 days & 45 days & & 25 Days & 35 days & 45 days \\
\hline PR 121 & 104.0 & 102.8 & 101.7 & & 103.1 & 101.1 & 99.8 \\
PR 122 & 99.2 & 100.9 & 98.8 & & 100.3 & 99.9 & 99.0 \\
PR 124 & 96.5 & 99.3 & 88.5 & & 96.9 & 93.5 & 86.9 \\
PR 126 & 106.6 & 100.3 & 89.9 & & 101.4 & 95.2 & 86.0 \\
LSD $(\mathrm{p}=0.05)$ & 7.3 & 6.0 & & & & \\
\hline
\end{tabular}


and PR 122, which was contributed by the highest panicles $\mathrm{m}^{-2}$ along with the bold grains, whereas the lower panicles $\mathrm{m}^{-2}$ and 1000 grain weight of PR 124 and PR 126 resulted into comparatively lower grain and straw yield. Kumar et al. (2018) also reported differences among genotypes for yield and yield attributes. However, differences in harvest index of genotypes did not reach the level of significance.

Data presented in Table 7 reveals that irrespective of genotypes, transplanting 25 days old seedlings resulted in the highest, whereas 45 days seedlings resulted in the least number of panicles per unit area. Data further brings out that increasing seedling age beyond 25 days did not affected number of panicles per unit area in PR 121 and PR 122 but increasing seedling age of PR 124 and PR 126 caused significant decline. Similar interactive effects were also noted for grain and straw yield of rice (Table $9 \& 10$ ). The reason for higher grain yield with the transplanting at optimum time is that, the crop gets more time to exploit a better sink development, more efficient and wider spreading root system, high carbohydrate and sink size which results in more translocation of assimilates from vegetative parts into spikelets during grain filling (Aghamolkiet al., 2015).

\section{CONCLUSION}

Among the two crop seasons, dry and warmer climatic conditions coupled with more sunny sky conditions during 2017 were favourable for achieving higher productivity and better heat use efficiency as compared to 2018. Also the incidence of rainfall during the September month which coincided with the grain growth period of rice is not favourable for rice crop. The critical analysis of the data revealed that PR 124 and PR 126 should be preferably be transplanted with younger (25 days) seedling while PR 121 and PR 122 can be transplanted using 25 to 45 days old seedlings. Further studies on genotypes specific planting window in relation to seedling age is needed for better understanding of the climatic factors underlying the yield formation of various rice genotypes.

\section{REFRENCES}

Aghamolki, M.T.K., Yusop, M.K., Jaafar, H.Z., Kharidah, S., Musa, M.H. andZandi, P.(2015). Preliminaryanalysis of growth and yield parameters in rice cultivars when exposed to different transplanting dates.Elec.J.Bio., 11: 147-153.

Dhillon, B.S.,Sharma, P.K. and Kingra, P.K. (2017). Agronomic measures to improvethermal energy utilization by spring sunflower. J.Agrometeorol., 19 (1): 34-38.

Faghani, R., Mobasser, H.R., Dehpor,A.A. and Kochaksarai, S.T. (2011).The effect of planting date and seedling age on yield and yield components of rice (Oryzasativa L.) genotypes in North of Iran. African J. Agric. Res.,6: 2571-2575.

Jia, X., Zhu, Q., Yang, Z., Sun, Y., Guo, X., Shi, Y. and Ma, J. (2014). Effect of seedling age on yield and population quality of mechanized transplanted hybrid rice. Trans. Chinese Soc. Agric. Eng., 30: 18-25.

Kaur, H. and Prabhjyot-Kaur. (2014). Effect of elevated temperature regimes on phenological development and heat unit requirements of rice (Oryza sativa $\mathrm{L}$.) cultivars. J. Agrometeorol., 16 (Special issue I): 95-100.

Kumar, S., Kumar, R., Mishra, J.S., Dwivedi, S.K., Prakash, V., Rao, K.K., Singh, A.K., Bhatt, B.P., Singh, S.S., Haris A.A., Kumar V., Srivastava, A.A., Singh, S. and Yadav, A. (2018). Productivity and profitability of rice (Oryza sativa) genotypes as influenced by crop management practices under middle Indo-Gangetic Plains. Indian J. Agron. 63 (1): 45-49.

Mobasser, H.R., Tari, D.B., Vojdani, M.,Abadi, R.S.andEftekhari, A. (2007). Effect of seedlings age and planting space on yield and yield Components of rice (Neda Genotype). Asian J. Pl. Sci., 6: 438-440.

Nuttonson, M.Y.(1955). Wheat climate relationships and use of phenology in ascertaining the thermal and photothermal requirement of wheat. American Institute of Crop Ecology, Washington DC: 338.

Prabhjyot-Kaur, Sandhu, S.S., Singh, H., Kaur, N., Singh, S. and Kaur, A. (2016).Climatic features and theirvariability in Punjab. AICRPAM, School of Climate Change and Agricultural Meteorology, PAU, Ludhiana. 78 pages.

Pramanik, K. andBera, A.K. (2013).Effect of seedling age and nitrogen fertilizer on growth, chlorophyll content, yield and economics of hybrid rice (OryzasativaL.).Int. J. Agron. Pl. Prod.,4: 3489-3499.

Rao, V.U.M., Singh, D.and Singh, R. (1999). Heat use efficiency of winter crops in Haryana. J. Agrometeorol., 1(2): 14348 